\title{
Pengetahuan, Asupan Energy dan Zat Gizi Berhubungan dengan Kekurangan Energy Kronis pada Wanita Prakonsepsi
}

Novika Hubu'1), Nuryani2) dan Yanti Hz Hano')

1I lmu Kesehatan Masyarakat, Fakultas Kesehatan Masyarakat, Universitas Gorontalo email: novikaharun336@gmail.com

2 I lmu Gizi, Fakultas Kesehatan Masyarakat, Universitas Gorontalo email: nuryanigz@gmail.com 3I lmu Kesehatan Masyarakat, Fakultas Kesehatan Masyarakat, Universitas Gorontalo email: yanti_hano@yahoo.co.id

\begin{abstract}
Choronic energy malnutrition is health problems in women reproductive age. The purpose of this study was assessed association between nutrition knowledge, energy and protein intake with chronic energy malnutrition. Design study was observational study with cross sectional design. The Sample were taken by exshautive sampling with collected 152 praconseption women. Study was conducted in Boalemo regency. Data analysis using univariate and bivariate analysis which was chi square test. The result showed that there were only 2,6\% in age less than 20 years, most of educational level les than nine years $66,4 \%$, $92,8 \%$ had occupation as house wife, $28,8 \%$ choronic energy malnutrition, 52,6\% low nutrition knowledge, 55,9\% low energy intake and $54,6 \%$ low protein intake. Bivariate analysis showed women who had CEM with low nutrition knowledge 51,3\% higher than high level of nutrition knowledge 2,7\%, low penergy intake 37,6\% higher than adequate energy intake $16,4 \%$, low protein intake $36,1 \%$ higher than adequate protein intake $18,8 \%$. Chi square test showed there were association between nutrition knowledge $(p=0,000)$, energy intake $(p=$ $0,007)$ and protein intake $(p=0,029)$ with chronic energy malnutrition in praconseption women. It was concluded tha low nutrition knowledge, low energy and protein intake had association with chronic energy malnutrion.
\end{abstract}

Keywords : Preconception, Knowedge, Energy Intake, Protein Intake

\section{PENDAHULUAN}

Angka kematian ibu menggambarkan jumlah wanita yang meninggal dari suatu penyebab kematian terkait dengan gangguan kehamilan atau penanganannya (tidak termasuk kecelakaan atau kasus insidentil) selama kehamilan, melahirkan dan dalam masa nifas (42 hari setelah melahirkan) tanpa memperhitungkan lama kehamilan per 100.000 kelahiran hidup (Kemenkes, 2012). Berdasarkan poin ke 5 target MDGs angka kematian ibu di Indonesia turun menjadi 118 pada tahun 2015 dan 102 pada tahun 2017 (Roeshadi, 2006). Tetapi pada kenyataannya angka kematian Ibu baru mencapai 228 per 100.000 
kelahiran hidup pada tahun 2007 (Kemenkes, 2012; SDKI, 2009). Penyebab utama kematian ibu di Negara berkembang dikenal dengan trias klasik yakni pendarahan, preeklampsia / eklampsia, dan infeksi (Duley et al., 2012; Eiland et al., 2012; Osungbade and Ige, 2011).

Salah satu masalah gizi yang di hadapi di Indonesia adalah masalah gizi pada masa kehamilan. Gizi pada masa kehamilan adalah salah satu faktor penting yang mempengaruhi perkembangan embrio dan janin serta status kesehatan ibu hamil. Kehamilan merupakan tahapan yang berkesinambungan, sehingga defesiensi pada suatu periode akan memberikan dampak secara berbeda pada outcome kehamilan. Periode perikonsepsional terdiri dari prekonsepi, konsepsi, implantasi, plasentasi, serta masa emriogenesis. Kualitas bayi yang dilahirkan sangat tergantung pada keadaan gizi ibu sebelum dan selama hamil (Celtin, 2009). Peran gizi sangat penting pada masa prakonsepsi (Roberts and Bodnar, 2007). Perbaikan gizi pada wanita prakonsepsi merupakan paradigma baru dalam menangani masalah gizi ibu hamil di Indonesia, mengingat keterlambatan ibu hamil adalah kontak pertama dengan pelayanan antenatal.

Kekurangan energy kronik (KEK) dapat memberikan dampak buruk bagi ibu dan janin. Kekurangan gizi pada ibu hamil dapat mempengaruhi proses pertumbuhan janin dan dapat menimbulkan keguguran, abortus, bayi lahir mati, kematian neonatal, cacat bawaan, anemia pada bayi, asfiksia intra partum (mati dalam kandungan) dan lahir dengan berat badan lahir rendah (BBLR). Efek jangka pendek KEK diantaranya anemia, perkembangan organ tidak optimal dan pertumbuhan fisik kurang, sehingga mengakibatkan kurang produktifnya seseorang (Waryono, 2010). KEK dapat diketahui dengan cara pengukuran lingkar lengan atas (LILA) dengan ambang batas (cut off point) kurang dari 23,5 $\mathrm{cm}$. Pengukuran mid-upper-arm circumference (MUAC) atau yang lebih dikenal dengan LILA dapat melihat perubahan secara paralel massa otot, sehingga bermanfaat untuk mendiagnosis kekurangan gizi (Gibson, 2005).

Periode prakonsepsi merupakan salah satu periode penting dalam mendukung perbaikan outcome pada masa kehamilan, namun masih terdapat sejumlah permasalahan gizi pada kelompok tersebut. Penelitian di Makassar mendapatkan sebanyak $20,0 \%$ status gizi kurang dan $9,1 \%$ mengalami berat badan lebih, pengukuran lingkar lengan atas menunjukkan 30,9\% KEK (Nuryani dkk, 2015). Sementara di Gianyar Bali kejadian KEK yakni 52,2\% (Adiputra dkk, 2018). Penelitian pada wanita usia reproduksi di Nepal mendapatkan 32,3\% mengalami berat badan kurang (Acharya et al., 2017). Sementara di India mendapatkan sebanyak $14,4 \%$ wanita usia reproduksi mengalami berat badan kurang (Manjunath et al., 2017).

Masalah KEK sering dikaitkan dengan pengetahuan gizi prakonsepsi. Menurut Proctor (2006), pengetahuan gizi prakonsespi merupakan faktor penting dalam mempersiapkan kehamilan. Hal ini bertujuan untuk mencegah terjadinya kekurangan asupan zat gizi selama kehamilan. Hasil penelitian Fauziyah (2014) di Kota Makassar menunjukkan bahwa wanita prakonsepsi yang berpengetahuan kurang memiliki peluang lebih besar untuk menderita KEK. Hasil penelitian lain menyatakan ada hubungan signifikan antara pengetahuan gizi dengan KEK dimana responden berpengetahuan gizi kurang memiliki peluang 3,852 kali menderita KEK dibandingkan responden berpengetahuan gizi baik (Simarmata, 2008). Hasil penelitian di Surakarta mendapatkan bahwa sebanyak 54\% wanita 
usia subur memiliki pengetahuan gizi prakonsepsi yang kurang (Umisah dan Puspitasari, 2017).

Asupan energi dan zat gizi kemungkinan berhubungan dengan status gizi pada wanita prakonsepsi. Hasil penelitian Irawan dkk (2014) pada wanita prakonsepsi mendapatkan asupan protein rata-rata 48,8 gr - 53,1 gr $(97,6 \%$ $106,25 \%$ angka kecukupan gizi / AKG) berdasarkan kelompok umur, terdapat hubungan yang signifikan antara asupan energi dan protein dengan indeks massa tubuh (IMT), namun tidak terdapat hubungan dengan lingkar lengan atas (LILA), analisis kategorik menunjukkan 57,8\% asupan energy kurang dan 17,2\% asupan protein kurang. Penelitian lain mendapatkan rata - rata asupan energy wanita prakonsepsi adalah $1.326,8 \mathrm{kkal}(60,3 \% \mathrm{AKG})$ dan asupan protein rata rata 53,05 gr (91,5\% AKG) (Nuryani dkk, 2015). Konsumsi makanan yang tidak adekuat berhubungan signifikan dengan status gizi pada wanita usia reproduksi (Ucharya et al., 2017).

Prevalensi KEK di Indonesia pada wanita hamil 24,2\% dan pada wanita usia reproduksi adalah 20,8\% sementara di Provinsi Gorontalo prevalensi KEK pada wanita hamil adalah 18,5\% sementara pada wanita usia subur adalah 19,3\% (Kemenkes, 2013). Di Provinsi Gorontalo masih terbatas kajian penelitian mengenai gizi pada wanita prakonsepsi, sehingga penelitian ini bertujuan untuk menilai hubungan antara pengetahuan gizi, asupan energy dan protein dengan kejadian kekurangan energy kronik (KEK) pada wanita prakonsepsi.

\section{METODE PENELITIAN}

Jenis penelitian adalah observasi dengan pendekatan analitik dan rancangan cross sectional study. Waktu penelitian adalah maret - april 2017 yang dilakukan di Kecamatan Tilamuta Kabupaten Bualemo. Populasi dalam penelitian ini adalah seluruh pasangan belum punya anak. Tehnik pengambilan sampel dengan cara exshaustive sampling atau total sampling yaitu pengambilan total jumlah keseluruhan wanita yang belum punya anak yakni 152 wanita prakonsepsi.

Variable penelitian meliputi status gizi, pengetahuan gizi, asupan energy dan asupan protein. Status gizi diukur menggunakan pita LILA untuk wanita usia subur, dikategorikan status gizi normal jika LILA $\geq 23,5 \mathrm{~cm}$ dan KEK jika < 23,5 $\mathrm{cm}$. Pengetahuan gizi adalah tingkat pengetahuan pada wanita prakonsepsi terkait gizi dan kesehatan diukur dengan menggunakan kuesioner. Pengetahuan gizi dikategorikan baik apabila hasil pengukuran pengetahuan gizi $\geq 50 \%$ skor benar dan dikategorikan pengetahuan kurang jika hasil pengukuran kuesioner < $50 \%$ skor benar. Variabel asupan total energy dan protein diukur menggunakan kuesioner recall 24 jam yang selanjutnya dibandingkan dengan angka kecukupan gizi (AKG) dikategorikan menjadi asupan energi dan protein cukup apabila asupan energy dan protein $\geq 80 \%$ AKG dan kateogri kurang apabila total asupan energy dan protein $<80 \%$ AKG.

Analisis data meliputi analisis univariat dan analisis bivariat. Analisis data asupan energy dan zat gizi menggunakan aplikasi nutrysurvey untuk mendapatkan total asupan energy dan zat gizi yang dikonsumsi oleh wanita prakonsepsi, sementara analisis data penelitian secara keseluruhan menggunakan aplikasi statistical package for social science (SPSS.18.0). Analisis univariat untuk memberikan gambaran dari masing - masing variabel. Analisis bivariat digunakan untuk menilai hubungan antara variabel pengetahuan gizi, 
Hubu,dkk

asupan energy dan protein dengan kejadian KEK. Uji chi squere test digunakan untuk melihat hubungan antara variabel dengan derajat kesalahan adalah $\mathrm{a}=$ 0,05 .

\section{HASIL DAN PEMBAHASAN}

\subsection{Analisis Karakteristik Wanita Prakonsepsi}

Gambaran karakteristik umur, tingkat pendidikan dan pekerjaan pada wanita prakonsepsi ditunjukkan pada Tabel 1. Karakteristik umur terdapat usia kurang dari 20 tahun hanya 2,6\%, paling banyak pada kategori usia 20 - 35 tahun yakni 97,4\%. Karakteristik tingkat pendidikan menunjukkan paling banyak pada tingkat pendidikan sekolah menengah atas (SMA) yakni $27,0 \%$ dan paling rendah pada jenjang pendidikan perguruan tinggi yakni hanya6,6\%. Karakteristik pekerjaan menunjukkan paling banyak wanita prakonsepsi bekerja sebagai ibu rumah tangga yakni 92,8\%.

Tabel 1. Gambaran Karakteristik, Tingkat Pengetahun Asupan Energy Dan Zat Gizi Wanita Prakonsepsi

\begin{tabular}{lcc}
\hline \multirow{2}{*}{ Karakteristik } & \multicolumn{2}{c}{ Jumlah } \\
\cline { 2 - 3 } Umur & $\mathrm{n}$ & $\%$ \\
$\quad<20$ tahun & 4 & 2,6 \\
$20-35$ tahun & 148 & 97,4 \\
Pendidikan & & \\
$\quad$ Sekolah Dasar & 61 & 40,1 \\
$\quad$ Sekolah Menengah Pertama & 40 & 26,3 \\
$\quad$ Sekolah Menengah Atas & 41 & 27,0 \\
$\quad$ Perguruan Tinggi & 10 & 6,6 \\
Pekerjaan & & \\
Ibu Rumah Tangga & 141 & 92,8 \\
$\quad$ Pegawai Negeri Sipil (PNS) & 6 & 3,9 \\
$\quad$ Wiraswasta & 5 & 3,3 \\
Status Gizi & & \\
$\quad$ KEK & 43 & 28,3 \\
$\quad$ Normal & 109 & 71,7 \\
Pengetahuan & & \\
$\quad$ Kurang & 80 & 52,6 \\
Baik & 72 & 47,4 \\
Asupan Energy (kkal) & & \\
$\quad$ Kurang & 85 & 55,9 \\
$\quad$ Cukup & 67 & 44,1 \\
Asupan Protein (kkal) & & \\
Kurang & 83 & 54,6 \\
Cukup & 69 & 45,4 \\
\hline$\quad$ Total & 152 & 100 \\
\hline
\end{tabular}

Gambaran tingkat pengetahuan, asupan energy dan zat gizi wanita prakonsepsi juga ditunjukkan pada Tabel 1. Karakteristik status gizi berdasarkan pengukuran lingkar lengan atas (LILA) menunjukkan sebanyak $28,3 \%$ memiliki status gizi kurang dan $71,7 \%$ dengan status gizi baik. Analisis tingkat pengetahuan gizi menunjukkan 52,6\% memiliki pengetahuan kurang 
dan 47,4\% dengan pengetahuan baik. Analisis asupan energy menunjukkan 55,9\% asupan kurang dan 44,1\% asupan baik, sementara asupan protein menunjukkan 54,6\% kategori kurang dan 45,4\% kategori baik.

Berdasarkan pengukuran LILA terdapat 28,3\% wanita prakonsepsi yang mengalami KEK. Kejadian KEK pada penelitian lebih rendah dibandigkan dengan hasil penelitian di Makassar mendapatkan 30,9\% wanita prakonsepsi mengalami KEK (Nuryani dkk, 2015). Demikian juga dengan yang ditemukan di Bali yakni 52,2\% ibu hamil primigravida mengalami KEK (Adiputra dkk, 2018).

Hasil penelitian ini menunjukkan masih banyak wanita prakonsepsi yang tidak memenuhi kebutuhan energy dan protein sesuai kebutuhan yang dianjurkan. Hal ini berbeda dengan hasil penelitian pada wanita prakonsepsi di Kota Makassar mendapatkan asupan protein pada kelompok usia 18 tahun dengan rata-rata $51 \mathrm{~g}(102 \%$ AKG), usia 19-29 tahun di 48,8 g (97,6\% AKG), dan kelompok usia> 30 tahun 53,1 g (106,2\% AKG) yang menunjukkan asupan protein adekuat (Irawan dkk, 2014). Akan tetapi hasil penelitian lain menemukan rata - rata asupan energy wanita prakonsepsi adalah 1.326,8 $\mathrm{kkal}(60,3 \% \mathrm{AKG})$ dan asupan protein rata - rata 53,05 gr (91,5\% AKG), hal menunjukkan bahwa rata - rata asupan energy masih sangat rendah dibandingkan AKG meskipun proporsi konsumsi protein tinggi (Nuryani dkk, 2015).

\subsection{Analisis Pengetahuan, Asupan Energy dan Protein dengan KEK pada Wanita Prakonsepsi}

Tabel 2. Analisis Hubungan Pengetahuan, Asupan Energy Dan Zat Gizi Dengan Kejadian Kekurangan Energy Kronis Pada Wanita Prakonsepsi

\begin{tabular}{|c|c|c|c|c|c|c|c|}
\hline \multirow{3}{*}{ Variabel } & \multicolumn{4}{|c|}{ Status Gizi } & \multirow{3}{*}{$\mathrm{n}$} & \multirow{3}{*}{$\%$} & \multirow{3}{*}{$\begin{array}{c}p \\
\text { value }\end{array}$} \\
\hline & \multicolumn{2}{|c|}{ KEK } & \multicolumn{2}{|c|}{ Normal } & & & \\
\hline & $\mathrm{n}$ & $\%$ & $\mathrm{n}$ & $\%$ & & & \\
\hline \multicolumn{8}{|l|}{ Pengetahuan } \\
\hline Baik & 2 & 2,7 & 70 & 97,3 & 72 & 47,4 & \multirow{2}{*}{0,000} \\
\hline Kurang & 41 & 51,3 & 39 & 47,8 & 80 & 52,6 & \\
\hline \multicolumn{8}{|c|}{ Asupan Energy } \\
\hline Cukup & 11 & 16,4 & 56 & 83,6 & 67 & 44,1 & \multirow{2}{*}{0,007} \\
\hline Kurang & 32 & 37,6 & 53 & 62,4 & 85 & 55,9 & \\
\hline \multicolumn{8}{|c|}{ Asupan Protein } \\
\hline Cukup & 13 & 18,8 & 56 & 81,2 & 69 & 45,4 & \multirow{3}{*}{0,029} \\
\hline Kurang & 30 & 36,1 & 53 & 63,9 & 83 & 54,6 & \\
\hline Total & 43 & 28,3 & 109 & 71,7 & 152 & 100 & \\
\hline
\end{tabular}

Analisis bivariat pengetahuan gizi dan status gizi kekurangan energy kronik pada wanita prakonsepsi ditunjukkan pada Tabel 2. Pada wanita prakonsepsi KEK terdapat 51,3\% memiliki pengetahuan gizi kurang lebih besar dibandingkan wanita prakonsepsi dengan pengetahuan gizi kategori baik yakni hanya 2,7\%, berbeda dengan kelompok wanita prakonsepsi dengan status gizi normal menunjukkan pengetahuan gizi kurang 47,8\% lebih rendah dibandingkan pengetahuan gizi kategori baik yakni $97,3 \%$. Rendahnya pengetahuan gizi pada wanita usia reproduksi juga ditemukan di Surakarta yakni 54\% dengan kategori pengetahuan kurang (Umisah dan Puspitasari, 2017). Hasil penelitian di Kota 
Tangerang Selatan juga mendapatkan pengetahuan gizi wanita prakonsepsi masih rendah yakni 50,7\% (Amalia, 2016).

Hasil analisis bivariat menunjukkan nilai $p$ value $=0,000$ yang menunjukkan terdapat hubungan antara tingkat pengetahuan gizi dengan kejadian KEK pada wanita prakonsepsi. Hasil penelitian ini sejalan dengan hasil penelitian di Makassar menunjukkan bahwa wanita prakonsepsi yang wanita prakonsepsi dengan pengetahuan kurang memiliki peluang lebih besar untuk menderita KEK, responden dengan pengetahuan gizi baik memiliki pencegahan 0,06 kali terhadap KEK dibandingkan responden dengan pengetahuan gizi kurang $(\mathrm{p}=0,000,95 \%$ CI $=0,01-0,27)$ (Fauziyah, 2014). Demikian halnya juga dengan penelitian Simarmata (2008) bahwa ada hubungan signifikan antara pengetahuan gizi dengan KEK dengan besar risiko 3,852 artinya responden berpengetahuan gizi kurang memiliki peluang 3,852 kali menderita KEK dibandingkan responden berpengetahuan gizi baik ( $p=0,009,95 \%$ CI =1,325-11,197) (Simarmat, 2008). Berbeda dengan penelitian Umisah dan Puspitasari (2017) yang mendapatkan tidak terdapat hubungan yang signifikan antara pengetahuan gizi dengan kejadian KEK pada wanita prakonsepsi $(p=0,179)$.

Pengetahuan gizi prakonsepsi merupakan faktor tidak langsung yang mempengaruhi kejadian KEK. Pengetahuan tentang bahan makanan akan mempengaruhi perilaku dalam pemilihan dan pengolahan makanan. Pengaruh pengetahuan gizi terhadap konsumsi makanan semestinya linier, artinya semakin tinggi tingkat pengetahuan gizi, diharapkan konsumsi makanan menjadi baik. Meskipun konsumsi makanan jarang terpenuhi oleh pengetahuan gizi sendiri tetapi merupakan interaksi sikap dan keterampilan dalam konsumsi makanan (Khomsan, 2000).

Analisis bivariat asupan energy dan status gizi kekurangan energy kronik pada wanita prakonsepsi ditunjukkan pada Tabel 2. Pada wanita prakonsepsi KEK terdapat 37,6\% dengan asupan energy kurang lebih banyak dibandingkan wanita prakonsepsi dengan asupan energy cukup yakni 16,4\%, berbeda dengan kelompok wanita prakonsepsi dengan status gizi normal menunjukkan asupan energy kurang 62,4\% lebih rendah dibandingkan asupan energy cukup yakni $83,6 \%$. Presentasi perbandingan asupan energy pada kelompok KEK hampir sama dengan penelitian Irawan dkk (2014) yakni asupan energy kurang $(29,7 \%)$ lebih besar dibandingkan asupan energy cukup $(25,9 \%)$.

Hasil analisis bivariat menunjukkan nilai $p$ value $=0,007$ yang menunjukkan terdapat hubungan antara asupan energy dengan kejadian KEK pada wanita prakonsepsi. Hal ini sesuai dengan penelitian Ernawati (2006) yang dilakukan di Semarang, menunjukan ada hubungan yang bermakna antara tingkat komsumsi energi dengan status gizi. Demikian halnya juga hasil penelitian di Nepal yang mendapatkan bahwa konsumsi makanan yang adekuat berhubungan signifikan dengan status gizi pada wanita usia reproduksi ( $\mathrm{p}=0,001)$ (Acharya et al., 2017). Penelitian lain menyatakan terdapat hubungan yang signifikan antara asupan energy dengan KEK pada wanita prakonsepsi $(\mathrm{p}=0,001)$ (Umisah dan Puspitasari, 2017). Hal ini didukung dengan pendapat Arnelia dan Sri Muljati (1991) yang mengatakan bahwa adanya penurunan status gizi disebabkan karena kurangnnya jumlah makanan yang dikomsumsi baik secara kualitas maupun kuantitas. Namun, hasil penelitian ini berbeda dengan penelitian Irawan dkk (2014) yang menyatakan tidak ada hubungan yang signifikan antara asupan energi dengan LILA $(\mathrm{p}=0,064, \mathrm{r}=0,192)$ meskipun pada indikator IMT 
menunjukkan adanya hubungan yang signifikan antara asupan energi dengan IMT ( $p=0,004, r=0,333)$.

Asupan energy yang rendah akan berdampak pada status gizi. Kurangnya asupan energy berpengaruh pada ketersediaan zat gizi lain seperti karbohidrat, protein, dan lemak yang merupakan sumber energi alternatif. Apabila tubuh kekurangan energi maka karbohidrat, protein atau lemak akan mengalami perubahan untuk menjadi sumber energi. Sehingga fungsi utama dari ketiga zat gizi tersebut akan menurun. Apabila berlangsung dalam waktu lama, akan terjadi perubahan berat badan dan kerusakan jaringan tubuh. Konsumsi energi yang tidak seimbang akan menyebabkan keseimbangan positif dan negatif. Kelebihan energi dari energi yang dikeluarkan akan diubah menjadi lemak sehingga terjadi kelebihan berat badan, hal ini juga dipengaruhi oleh aktivitas. Sebaliknya asupan energi kurang dari yang dikeluarkan maka akan terjadi keseimbangan energy negatif, akibatnya berat badan lebih rendah dari ideal.

Analisis bivariat asupan protein dan status gizi kekurangan energy kronik pada wanita prakonsepsi ditunjukkan pada Tabel 2. Pada wanita prakonsepsi KEK terdapat $36,1 \%$ dengan asupan protein kurang lebih besar dibandingkan wanita prakonsepsi dengan asupan protein cukup yakni 18,8\%, berbeda dengan kelompok wanita prakonsepsi dengan status gizi normal menunjukkan asupan protein kurang 63,9\% lebih rendah dibandingkan asupan protein cukup yakni $81,2 \%$. Hampir sama dengan hasil penelitian Umisah dan Puspitasari (2017) yang mendapatkan sebesar 56,8\% wanita prakonsepsi mengkonsumsi protein kurang. Hasil analisis perbandingan asupan protein berbeda dengan temuan di Makassar yakni pada kelompok KEK asupan protein kurang 27,3\% lebih rendah dibandingkan asupan protein cukup yakni 28,3\% (Irawan dkk, 2014).

Hasil analisis bivariat menunjukkan nilai $p$ value $=0,029$ yang menunjukkan terdapat hubungan antara asupan protein dengan kejadian KEK pada wanita prakonsepsi. Hasil penelitian ini sesuai dengan hasil penelitian di Surakarta yang mendapatkan adanya hubungan antara asupan protein dengan KEK ( $p=0,001)$ (Umisah dan Puspitasari, 2017). Berbeda dengan hasil penelitian di Makassar yang mendapatkan bahwa tidak ada hubungan yang signifikan dengan LILA ( $\mathrm{p}=$ $0,333), r=0,055)$, akan tetapi terdapat hubungan yang signifikan antara asupan protein dengan IMT ( $\mathrm{p}=0,044, \mathrm{r}=0,215)$ (Irawan dkk, 204), tidak ditemukan hubungan antara konsumsi zat gizi dengan KEK karena indikator pengukuran status gizi menggunakan lingkar lengan atas (LILA). Kejadian KEK menggambarkan keadaan akibat kekurangan energi atau ketidakseimbangan asupan energi untuk memenuhi kebutuhan tubuh yang berlangsung dalam waktu yang lama (Supariasa, 2001). KEK terepresentasikan pada pengukuran lingkar lengan atas $<23,5 \mathrm{~cm}$, sehingga instrumen yang dapat digunakan untuk menilai KEK sebaiknya menggunakan food frequency.

Asupan energi dan protein kurang akan berdampak negatif bagi wanita prakonsepsi dan janin yang dikandungnya apabila mengalami kehamilan. Protein berperan penting sebagai pembangun struktur jaringan tubuh dan berperan penting pada saat konsepsi. Selain itu protein memiliki fungsi yang sangat penting dalam tubuh manusia, yakni sumber energi setelah glikogen, protein juga menjadi katalis bagi reaksi biokimia dalam tubuh. Selain itu protein digunakan sebagai penyusun struktur sel dan jaringan. Sehingga asupan protein harus cukup, karena kekurangan protein akan berdampak buruk pada seorang 
Hubu, dkk

individu, utamanya pada ibu prakonsepsi. Apalagi kondisi ini berlangsung dalam jangka waktu yang lama.

\section{KESIMPULAN DAN SARAN}

Disimpulkan bahwa prevalensi KEK pada wanita prakonsepsi 28,3\%. Terdapat hubungan antara pengetahuan gizi, asupan energy dan protein dengan kejadian KEK pada wanita prakonsepsi. Diperlukan pengembangan research dengan kelompok subjek wanita prakonsepsi yang lebih besar serta pengukuran variabel yang lebih komprehensif mengingat bahwa masalah gizi tidak disebabkan oleh faktor tunggal saja, tetapi interkorelasi antara beberapa faktor.

\section{REFERENSI}

Acharya SR, Bhatta J, Timilsina DP. 2017. Factors associated with nutritional status of women of reproductive age group in rural, Nepal. Asian fasific journal of health sciences. vol 4 (4): $19-24$.

Adiputra KP, Pinatih IGNI, Seriani L. 2018. Perbedaan persiapan prakonsepsi ibu hamil primigravida yang mengalami kurang energi kronik dan tidak kurang energi kronik di Puskesmas Gianyar 1 periode Januari-Agustus 2017. Ejurnal medika udayana. Vol 7(3): 121 - 124.

Arnelia dan S Muljati. 1991. Status Gizi Anak Balita PengunjungPosyandu Kecamatan Ciomas dan Samplak, Kabupaten Bogor. Universitas Diponegoro.

Amelia AN. Hubungan pengetahuan, sikap dengan perilaku makan sumber energy pada wanita prakonsepsi yang dilayani KUA KecamatanPamulang Kota Tangerang Selatan Tahun 2016. Skripsi (tidak diterbitkan). Universitas Islam Indonesia (UIN) Syarif Hidayatullah. Jakarta.

Celtin. 2009. Role of micronutrients in the pereinceptional period. Human Reprod. Vol. 16.

Duley L, Henderson-Smart DJ, Meher S. 2012. Altered Dietary Salt for Preventing Pre-Eclampsia, and Its Complications (Review). Intervention Review The Cochrane Collaboration. JohnWiley \& Sons Ltd. Nottingham.

Ernawati A. 2006. Hubungan Faktor Sosial Ekonomi, Higiene Sanitasi Lingkungan, Tingkat Konsumsi dan Infeksi dengan Status Gizi Anak Usia 2-5 Tahun di Kabupaten Semarang Tahun 2003. Universitas Diponegoro. Semarang.

Eiland E, Nzerue C, Faulkner M. 2012. Review Article: Preeclampsia 2012. Journal of Pregnancy: 1-7.

Fauziyah H. 2014. Analisis Faktor Risiko Kekurangan Energi Kronik (KEK) pada Wanita Prakonsepsi di Kota Makassar. (Skripsi) Universitas Hasanuddin. Makassar.

Gibson RS. 2005. Principle Of Nutritional and Assesment. Oxford University Press. New York.

Irawan AMS, Thaha AR, Virani D. 2014. Hubungan asupan energy dan protein dengan status IMT dan LILA ibu prakonsepsional di Kecamatan Ujung Tanah dan Biringkanaiyya Kota Makassar. Skripsi (Tidak diterbitkan). Universitas Hasanuddin. Makassar.

Khomsan A. 2000. Pangan dan Gizi untuk Kesehatan. Rajawali Sport. Jakarta.

Kementerian Kesehatan Republik Indonesia. 2013. Riset Kesehatan Dasar (Riskesdas) 2013. Kementerian Kesehatan Republik Indonesia. Jakarta. 
Kementerian Kesehatan Republik Indonesia. 2013. Profil Kesehatan Indoensia 2012. Kementerian Kesehatan Republik Indonesia. Jakarta.

Manjunath TL, Shilu MZ, Mahesh V, Muninarayana C, Ananya L. 2017. Nutritional assessment of women in the reproductive age group (15-49 years) from a rural area, Kolar, Kerala, India. International Journal of Community Medicine and Public Health. Vol 4(2): 542 - 546.

Nuryani, Thaha AR, Jafar N. 2015. Pengaruh pemberian multi gizi mikro terhadap hematokrit, leukosit dan trombosit pada wanita prakonsepsi. (Thesis). Universitas Hasanuddin. Makassar.

Osungbade KO and Ige OK. 2011. Public health perspectives of preeclampsia in developing countries: Implication for health system strengthening. $J$ Pregnancy. 481095.

Proctor J. 2006. Preconception Nutrition Knowledge, Dietary Intakes And Lifestyle Characteristics Of Auckland Women. Tesis. Massey University. New Zealand.

Roberts JM and Bodnar LM. 2007. Report On The Wic Nutrition Risk Criterion For Hypertension In Pregnancy. Prepared for the US Department of Agriculture, Food and Nutrition Service July 2007. Magee-Womens Research Institute: Pittsburgh.

Roeshadi RH. 2006. Upaya Menurunkan Angka Kesakitan dan Angka Kematian Ibu pada Penderita Preeklampsia dan Eklampsia. Pidato Pengukuhan Guru Besar Fakultas Kedokteran Universitas Sumatera Utara. http:/ / repository.usu.ac.id/ bitstream/123456789/721/1/ Haryo no.pdf.

SDKI. 2009. Profil Kesehatan Indonesia 2008. Departemen Kesehatan Republik Indonesia Tahun 2009. http://www.depkes.go.id/downloads / publikasi/Profil $\% 20$ Kesehatan\%20Indonesia\%202008.pdf.

Simarmata M. 2008. Hubungan Pola Konsumsi, Ketersediaan Pangan, Pengetahuan Gizi dan status Kesehatan dengan Kejadian KEK pada Ibu Hamil di Kabupaten Simalungun. (Tesis). Universitas Sumatera Utara. Medan.

Supariasa. 2001. Penilaian Status Gizi. Buku Kedokteran EGC. Jakarta.

Umisah IN dan Puspitasari DI. 2017. Perbedaan pengetahuan gizi prakonsepsi dan tingkat konsumsi energi protein pada wanita usia subur (WUS) usia 15-19 tahun kurang energi kronis (KEK) dan tidak kek di SMA Negeri 1 Pasawahan. Jurnal kesehatan. Vol 10(2): 23 - 36.

Waryono. 2010. Gizi Reproduksi. Pustaka Rihama. Yogyakarta 